constant, here assumed to be $0.585 \times 10^{-10} \mathrm{yr}^{-1}$ and $\lambda B$ the $B^{-}$emission decay constant $4.76 \times 10^{-10} \mathrm{yr}^{-1}$.

The results are summarized in Table 2.

TABLE 2

\begin{tabular}{|c|c|c|c|c|c|c|}
\hline $\begin{array}{l}\text { Specimen } \\
\text { No. }\end{array}$ & $\begin{array}{l}\text { Analysis } \\
\text { Ref. No. }\end{array}$ & $\begin{array}{l}\text { Wt. of } \\
\text { sample } \\
\text { loaded } \\
\text { (gm.) }\end{array}$ & $\underset{\%}{\mathrm{~K}_{2} \mathrm{O}}$ & $\begin{array}{l}\text { Total } \\
\text { vol. of } \\
\text { argon } \\
\left.\left(\mathrm{mm}^{3}\right)^{3}\right)\end{array}$ & $\begin{array}{l}\text { Atmo- } \\
\text { spheric } \\
\text { contamina- } \\
\text { tion } \%\end{array}$ & $\begin{array}{l}\text { Apparent } \\
\text { age, } \\
\text { million } \\
\text { years }\end{array}$ \\
\hline U 1368 & $\mathrm{KA} / 30$ & $6 \cdot 0013$ & $8 \cdot 32$ & 0.847 & 7 & 429 \\
\hline R $\quad 83$ & $\mathrm{KA} / 48$ & $8 \cdot 5126$ & $8 \cdot 67$ & $1 \cdot 220$ & 4 & 434 \\
\hline S 1716 & $\mathrm{KA} / 45$ & $7 \cdot 2330$ & $7 \cdot 99$ & 0.990 & 7 & 431 \\
\hline U 2228 & $\mathrm{KA} / 2$ & 6.0544 & $6 \cdot 82$ & 0.668 & 2 & 434 \\
\hline V 261 & $\mathrm{KA} / 33$ & $7 \cdot 6398$ & $7 \cdot 36$ & $1 \cdot 032$ & 14 & 426 \\
\hline V 1127 & $\mathrm{KA} / 31$ & $8 \cdot 1040$ & $8 \cdot 50$ & $1 \cdot 20$ & 7 & 441 \\
\hline V 1398 & $\mathrm{KA} / 25$ & $5 \cdot 1634$ & $7 \cdot 55$ & 0.632 & 2 & 434 \\
\hline
\end{tabular}

Average $433 \pm 8$ (range of extremes).

Errors in these apparent ages introduced by the experimental procedure are believed not to be more than \pm 5 per cent.

These results indicate that the Moine Series of Scotland was subjected to regional metamorphism during Silurian (Holmes, 1959) times. Their consistency suggests that they have not since then undergone any disturbances, apart from localized intrusions, that have resulted in the serious loss of radiogenic argon from the micas formed as a result of this metamorphism. The existence of any previous episodes of regional metamorphism has not been proved or disproved by this work, neither has information been obtained on the actual age of the Moine sediments themselves.

Three hypotheses regarding the age of metamorphism, based on geological evidence, have been advanced (Phemister, 1948), namely, (a) Lewisian, (b) post-Lewisian but pre-Torridonian, (c) Caledonian. Much of present-day opinion is in favour of the view $(c)$, which these results support.

This is part of a project sponsored by the Department of Scientific and Industrial Research. I am indebted to the Royal Dutch Shell Oil Company for a studentship.

Department of Geodesy and Geophysics,

JoHn A. Miller.

CAMBRIDGE.

29 th September, 1960.

\title{
REFERENCES
}

Holmes, A., 1959. Trans. Edin. Geol. Soc., vol. 17, part 3, pp. 183-216.

Phemister, J., 1948. British Regional Geology. Scotland. The Northern Highlands (Second Edition). H.M. Stationery Office.

\section{AGE OF MOUNTSORREL GRANITE}

SIR,-The granite or granodiorite of Mountsorrel, situated some seven miles to the north of Leicester, England, is a large intrusive boss more than a mile in diameter, and projects through the Trias to give a series of isolated outcrops. Two varieties of this coarsely-crystalline rock exist and are distinguished by their pink and grey feldspars.

The age of this intrusion has long been in doubt. It is older than the 
overlying Triassic sandstones, but is not similar to other igneous rocks of Charnwood Forest. It appears to be later than the Charnian syenites since it has not been subjected to N.W.-S.E. movements which affect them. At Kinchley, a diorite said to be associated with the granite is intruded into slates which are probably members of the Swithland group, the uppermost member of the Charnian pyroclastic sequence. On the other hand the granite is itself cut by dolerite dykes of Carboniferous age. Thus it is preCarboniferous and younger than some pre-Cambrian rocks of Charnwood Forest. Petrologically it has affinities with the Caledonian group of granites. The above situation was summarized by Watts (1947).

Measurements of geological age have been carried out on three samples of Mountsorrel granite using the potassium-argon method. Biotites were isolated from the material by a process of grinding, sieving, and magnetic separation, then analysed for their potassium oxide content flame-photometrically (see Table I).

TABLE I.-Results of potassium oxide analyses

\begin{tabular}{c|c|c}
$\begin{array}{c}\text { Analyses } \\
\text { Reference } \\
\text { number }\end{array}$ & $\begin{array}{c}\mathrm{K}_{2} \mathrm{O} \text { per cent } \\
\text { (each average of thirty readings) }\end{array}$ & $\begin{array}{c}\mathrm{K}_{2} \mathrm{O} \text { per cent } \\
\text { of sample } \\
\text { (average of six } \\
\text { determinations) }\end{array}$ \\
\hline $\mathrm{KA} / 40$ & $5 \cdot 53,5 \cdot 50,5 \cdot 35,5 \cdot 35,5 \cdot 50,5 \cdot 50$, & $5 \cdot 46$ \\
$\mathrm{KA} / 52$ & $6 \cdot 18,6 \cdot 17,6 \cdot 18,6 \cdot 18,6 \cdot 18,6 \cdot 18$, & $6 \cdot 18$ \\
$\mathrm{KA} / 53$ & $5 \cdot 65,5 \cdot 66,5 \cdot 66,5 \cdot 66,5 \cdot 66,5 \cdot 67$, & $5 \cdot 66$ \\
\hline
\end{tabular}

The extraction of argon, its purification and measurement were carried out in an argon line connected directly to the mass spectrometer. Thus samples were corrected for their atmospheric argon content without any risk of contamination arising during the transfer of gas from the former to the latter. This system also has the advantage that any residual background in the argon line itself may be examined and corrected for. The results together with errors and physical constants used in the calculations are given in Table II.

Results of potassium-argon dating thus indicate that the Mountsorrel Granite is Caledonian in age.

The total error resulting from uncertainties in volume, potassium oxide content, and $\mathrm{A}^{40} / \mathrm{A}^{36}$ ratio of the sample should not exceed \pm 5 per cent.

TABLE II

\begin{tabular}{|c|c|c|c|c|c|c|}
\hline \multirow{2}{*}{ Sample } & \multirow{2}{*}{$\begin{array}{c}\text { Record } \\
\text { Ref. }\end{array}$} & Vol. of argon (mm. $\left.{ }^{3}\right)$ & \multirow{2}{*}{$\begin{array}{l}\text { Atmospheric } \\
\text { contamina- } \\
\text { tion, } \\
\text { per cent }\end{array}$} & \multirow{2}{*}{$\delta \mathrm{V}_{\boldsymbol{x}}$} & \multirow{2}{*}{$\delta \mathrm{t}$} & \multirow{2}{*}{$\begin{array}{l}\text { Age (t) } \\
\text { (millions } \\
\text { of years) }\end{array}$} \\
\hline & & Wt. of sample (gm.) & & & & \\
\hline $\begin{array}{l}\mathrm{KA} / 40 \\
\mathrm{KA} / 52 \\
\mathrm{KA} / 53\end{array}$ & $\begin{array}{l}G / 21 \\
G / 17 \\
G / 18 \\
G / 19 \\
G / 20\end{array}$ & $\begin{array}{l}0.0839 \\
0.0958 \\
0.101 \\
0.0894 \\
0.088\end{array}$ & $\begin{array}{l}3 \cdot 1 \\
4 \cdot 1 \\
5 \cdot 6 \\
5 \cdot 5 \\
4 \cdot 6\end{array}$ & $\begin{array}{l}0 \cdot 2 \\
0 \cdot 3 \\
0 \cdot 5 \\
0 \cdot 5 \\
0 \cdot 2\end{array}$ & $\begin{array}{l}3 \cdot 63 \\
3 \cdot 63 \\
3 \cdot 74 \\
3 \cdot 46 \\
3 \cdot 62\end{array}$ & $\begin{array}{l}404 \\
403 \\
417 \\
405 \\
402\end{array}$ \\
\hline
\end{tabular}

$\delta \mathrm{V}_{\mathbf{r}}=$ percentage standard deviation in volume of radiogenic argon due to uncertainty in isotopic ratios of specimen.

$\delta \mathrm{t}=$ error in age (in million years) due to a 1 per cent error in proportion of $\mathrm{K}_{2} \mathrm{O}$ or volume of radiogenic argon. 
We wish to thank the Mountsorrel Granite Company for allowing us to visit their quarry and collect samples. We are indebted to the Department of Scientific and Industrial Research for financing the work and to the Royal Dutch Shell Oil Company for a studentship to one of us (J. A. M.).

Department of Geodesy and Geophysics, JiLL S. PODMORE.

CAMBRIDGE.

1st October, 1960.

\section{REFERENCE}

WATIS, W. W. 1947. Geology of the ancient rocks of Charnwood Forest, Leicestershire, Leicester.

\section{DISCOVERY OF COPPER MINERALS IN LEWISIAN GNEISS}

Sir,-The presence of traces of copper ore has not, so far as the writers are aware, been reported in the Lewisian gneiss of north-west Scotland. An occurrence of copper-bearing minerals was found by us recently in the gneiss about one quarter of a mile south-east of the Bay of Clachtoll, near Stoer, Sutherland (Grid reference : 041267). The minerals form patches in the gneiss some two square inches in diameter over an area of about one square yard. Near the mineral locality there is a talc, anthophyllite dyke with which the occurrence may or may not be associated. Intensive search in the neighbourhood has failed to locate any other occurrence of copper minerals in the Lewisian gneiss.

The presence of copper minerals occurring in the Torridonian beds of this region was reported by Sir Lewis Fermor in the Geological Magazine (Geol. Mag. lxxxviii, 1951, pp. 215-218), who gave their locus " on the promontory separating the Bay of Clachtoll on the south from the Bay of Stoer on the north ". It is not suggested, however, that there is necessarily any relationship between these occurrences.

Although we failed to find further traces of copper minerals in the Clachtoll area, minute quantities were found by Mr. A. K. MacLeod of Inverkirkaig, in the gneissic rocks of a quarry alongside the road bordering Loch an Eisg-brachaidh, about a mile south of Loch Kirkaig (Grid reference : 073178). Unfortunately, soon after these specimens were found, the quarry suffered a severe rock-fall, rendering further investigation both unproductive and dangerous. Smears of copper compounds were, however, detected on rock faces in another small quarry at the top of the hill in which the occurrence of harmotome crystals has been recorded by Waterston (Miner. Mag., xxx, 1953, pp. 136-138).

The minerals at Clachtoll consist principally of brochantite $\left[\mathrm{Cu}_{4}(\mathrm{OH})_{6} \mathrm{SO}_{4}\right]$, accompanied by small amounts of quartz, iron oxide and chlorite ; but malachite, chalcocite, covellite and bornite were also found in associated specimens. The samples found at Eisgbrachaidh consist mainly of malachite accompanied by haematite.

The writers are indebted for these identifications to Dr. Diane C. Knill and Mr. B. R. Young of the Geological Survey, London; and to Mr. P. McL. D. Duff of the Grant Institute of Geology, Edinburgh, whose help is greatly appreciated.

Rock specimens containing these cupriferous deposits have been presented to the Geological Museum, London (Nos. M.1. 30217/30371/30373) ; and to the Geological Department of the Royal Scottish Museum, Edinburgh (No. 1959. 5).

\footnotetext{
INVERKIRKAIG,

NR. LOCHINVER,

VIA LAIRG, SUTHERLAND.

15th August, 1960.
}

Alex J. Boyd and James M. Crichton. 